\title{
Study on Enzymatic Degradation of Cornstalk in Ionic Liquid
}

\author{
Xianhong Liu $\cdot$ Lu Li $\cdot$ Shitao Yu $\cdot$ Nannan Zhu \\ Zhongliang Su $\cdot$ Shiwei Liu $\cdot$ Fusheng Liu $\cdot$ \\ Congxia Xie $\cdot$ Baoquan Zhang $\cdot$ Chenggang Zhang
}

Received: 3 September 2013/Accepted: 26 October 2013/Published online: 23 November 2013

(C) The Author(s) 2013. This article is published with open access at Springerlink.com

\begin{abstract}
The influence of reaction conditions on the enzymatic degradation of cornstalk in the system of 1-ethyl-3-methylimidazolium acetate ([EMIM]OAc) was investigated. The optimum condition was as follows: $5 \mathrm{~g}$ $4 \mathrm{wt} \%$ cornstalk in ionic liquid solution, $3.64 \mathrm{~mL} \mathrm{pH} 5$ citric acid-sodium citrate buffer solution, the concentration of cornstalk $55 \mathrm{mg} / \mathrm{mL}$, the ratio of enzyme and cornstalk $0.5 \mathrm{~mL} / \mathrm{g}$, reaction temperature $55^{\circ} \mathrm{C}$ and reaction time $30 \mathrm{~h}$. Under the optimum condition, the rate of enzymatic degradation was $96.6 \%$, and was 2.1 times quicker than under the conventional condition. The changes of the molecular structure of cornstalk dissolved in [EMIM]OAc were detected by FT-IR and SEM. It was also found that ionic liquid [EMIM]OAc had good reusability.
\end{abstract}

X. Liu $(\bowtie) \cdot$ L. Li $\cdot$ S. Yu - N. Zhu · Z. Su - S. Liu - F. Liu College of Chemical Engineering, Qingdao University of

Science and Technology, 53 Zhengzhou Road, Qingdao 266042,

People's Republic of China

e-mail: 18766270353@139.com

S. Yu

e-mail: yushitaoqust@126.com

C. Xie

Key Laboratory of Eco-Chemical Engineering, Ministry of Education, College of Chemistry and Molecular Engineering, Qingdao University of Science and Technology, 53 Zhengzhou Road, Qingdao 266042, People's Republic of China

\section{B. Zhang}

College of Materials Science and Engineering, Qingdao

University of Science and Technology, 53 Zhengzhou Road,

Qingdao 266042, People's Republic of China

\section{Zhang}

Qingdao Bioshine.Co., Ltd., 5315 Zhengzhou Qinling Road,

Qingdao 266061, People's Republic of China
Keywords Ionic liquid $\cdot$ Cornstalk $\cdot$ Enzymatic degradation

\section{Introduction}

As the depletion of fossil fuel and environmental destruction has become increasingly serious, the production of renewable energy with green processes has received a wide attention [1]. Biomass resource, such as cornstalk, is one of the most promising sources to generate biomass-based energy [2]. The output of cornstalk is more than seven hundred million tons per year, but the utilization rate is less than $30 \%$. Most cornstalk is used as fuel or fertilizer, the utilization efficiency is low and can result in environmental pollution [3]. In this context, the development and effective utilization of the cornstalk for fuels such as ethanol, acetone, butanol and chemical raw materials have practical importance $[4,5]$. Enzyme-assisted processes for conversion of cornstalk are usually performed in relatively mild reaction conditions with high specificity, which have been considered as alternative "green" approaches compared with acid hydrolysis [6]. However, the enzymatic degradation of cornstalk suffers from slow reaction rates due in large part to the highly crystalline structure of cornstalk and inaccessibility of enzyme adsorption. Various physical and chemical pretreatment methods, which include steam explosion [7], high pressure [8], dilute acid [9] and mild alkaline peroxide pretreatments [10], are currently employed to improve the degradation of cornstalk. However, these pretreatment methods are often energy intensive, and might produce undesirable byproducts.

Ionic liquids (ILs) have been increasingly recognized as novel solvents for dissolution and pretreatment of cellulose [11-15]. ILs are a group of salts that exist as liquids at relatively low temperatures $\left(<100{ }^{\circ} \mathrm{C}\right)$ and exhibit many properties such 
as high thermal stability, negligible vapor pressure and low impact on the environment and human health; thus, ILs have been recognized as solvents for green chemistry [16, 17]. The near limitless potential to combine anions and cations in order to tailor solvent properties has led to ILs being termed as "designer solvents" [18]. Recently, several studies [19, 20] demonstrated that [EMIM]OAc was chosen as an environmental friendly solvent for enzymatic in situ saccharification in view of its biocompatibility with both cellulose solubility and enzyme activity. XuCuizhi [21] in our laboratory investigated the enzymatic degradation of microcrystalline cellulose in the aqueous-ionic liquid system of [EMIM]OAc and cellulose. The result demonstrated the rate of enzymatic degradation achieved $78.5 \%$ under the optimum condition. This research realized the efficient and green degradation of microcrystalline cellulose, also provided a feasible route for development and utilization of biomass resources.

In this study, the enzymatic degradation of cornstalk in the system of [EMIM]OAc was investigated. The rate of enzymatic degradation in situ under the system of IL was compared with the rate under the conventional condition, and the reason was researched by FT-IR and SEM. The influence of reaction conditions on the results of degradation was examined and the reusability of the ionic liquid was discussed.

\section{Experimental}

\subsection{Materials and Equipment}

The cornstalk sample was laboratory-prepared by a Soxhlet extraction process, and the degree of polymerization (DP) of cornstalk was 800. Cellulase (activity 280 FPU) was from Continent Biotech(Shanghai)Co. The IL ([EMI$\mathrm{M}] \mathrm{OAc}$ ) was laboratory-synthesized according to the Ref. [22]. The DNS reagent was from Qingdao Zhengye Ltd. All other reagents were analytical grade and used without further purification.

IR spectra were recorded with a Nicolet 510P FT-IR spectrometer in the range of 2,000-800 $\mathrm{cm}^{-1}$, using $\mathrm{KBr}$ powder containing ca. $1 \mathrm{wt} \%$ of sample. SEM images were taken for both original cornstalk and cornstalk treated with [EMIM]OAc using a Hitachi S-5000 microscope, where samples were coated with a thin layer of gold in an automatic sputter coater before observation. The accelerating voltage was $5 \mathrm{kV}$, and images of the samples were acquired at 5,000 magnification.

\subsection{Ingredient Measurement of Cornstalk Material}

The compositions of cornstalk material were determined according to GB/T 2667.10-1995. And the data is shown in Table 1 .
Table 1 The ingredient of cornstalk

\begin{tabular}{lllll}
\hline $\begin{array}{l}\text { Composite } \\
\text { content }\end{array}$ & $\begin{array}{l}\text { Cellulose } \\
(\%)\end{array}$ & $\begin{array}{l}\text { Hemicellulose } \\
(\%)\end{array}$ & $\begin{array}{l}\text { Lignin } \\
(\%)\end{array}$ & $\begin{array}{l}\text { Ash } \\
(\%)\end{array}$ \\
\hline Cornstalk & 42.95 & 28.9 & 20.6 & 7.52 \\
\hline
\end{tabular}

2.3 Enzymatic Degradation of Cornstalk in [EMIM]OAc System

The [EMIM]OAc (4.8 g) was placed into a clear $50 \mathrm{~mL}$ flask equipped with magnetic stirrer and thermometer. Then the equipment was placed into a heating water bath. Small precise amount of dry cornstalk (0.2 g) was added discretely into the flask. The mixture was stirred for dissolution until the solution was fully transparency and $4 \mathrm{wt} \%$ cornstalk/ionic liquid solution was obtained. A certain volume of buffer solution was added to the system to decrease the viscosity of solution and provide the needed water in the degradation of cornstalk. The enzymatic degradation reaction was initiated by adding cellulase liquid $(100 \mathrm{mg} / \mathrm{mL})$ to the aqueous-IL mixture. The enzymatic solution was vortex mixed, and then the enzymatic degradation was carried out in a constant temperature flask for a certain time.

\subsection{Control Experiment}

The [EMIM]OAc (4.8 g) was placed into a clear $50 \mathrm{~mL}$ flask equipped with magnetic stirrer and thermometer. Then the equipment was placed into a heating water bath. Small precise amount of dry cornstalk (0.2 g) was added discretely into the flask. The mixture was stirred for dissolution until the solution was fully transparency and $4 \mathrm{wt} \%$ cornstalk/ionic liquid solution was obtained. A certain volume of buffer solution was added to the system to decrease the viscosity of solution and provide the needed water in the degradation of cornstalk. $0.5 \mathrm{~mL}$ solution mixed uniformly was removed as control.

\subsection{Measurement of the Rate of Enzymatic Degradation}

The rate of enzymatic degradation was evaluated by quantifying the reducing sugar released after a certain time. The quantity of reducing sugar was determined by the dinitrosalicylic acid (DNS) method [23].

The rate of enzymatic degradation was calculated as follows:

Quantity of reducing sugar $=$ concentration of reducing sugar $\times 0.9 \times$ dilution multiple $\times$ dilution volume

The rate of enzymatic degradation $(\%)=$ quantity of reducing sugar/(dry weight of cornstalk) $\times 100 \%$. 


\subsection{Reusability Measurement of IL}

When water was added to the reaction solution at concentrations greater than ca. $1 \mathrm{wt} \%$ (approximately $0.5 \mathrm{~mol}$ fraction $\mathrm{H}_{2} \mathrm{O}$ ) the solvent properties were significantly impaired, and cellulose was no longer soluble. In this way the regenerated cellulose was obtained at room temperature. The regenerated cellulose and water were removed by filtration and vacuum distillation respectively, and the recycled ionic liquid was obtained. The recycled ionic liquid was weighed each time for calculating the rate of recovery. The reusability of recycled IL as solvent was evaluated with the rate of enzymatic degradation.

\section{Results and Discussion}

\subsection{FT-IR Spectra Analyses}

To explain why [EMIM]OAc enhanced enzymatic hydrolysis of cornstalk, the FT-IR spectra of original cornstalk and cornstalk treated with [EMIM]OAc were analyzed. The FT-IR spectroscopy (Fig. 1) indicated that the skeleton structure of original cornstalk and cornstalk treated with [EMIM]OAc were basically same. These data suggested that cornstalk was dissolved directly in [EMIM]OAc, and derivatization reaction did not happen [24]. As shown in the FT-IR spectrum (a) of original cornstalk, the broad stretching vibration peak of $\mathrm{O}-\mathrm{H}$ groups was near $3,414 \mathrm{~cm}^{-1}$. However, the representative peak of cornstalk treated with [EMIM]OAc was near $3,430 \mathrm{~cm}^{-1}$, as shown in the FT-IR spectrum (b). In comparison with original cornstalk, the peak position of cornstalk treated with [EMIM]OAc was migrated and the intensity was weakened. This may be due to the weakening of hydrogen bonds in the cornstalk molecule or the emergence of cooperation in the process of dissolution [25]. As shown in FT-IR spectrum (a), the bending vibration of $\mathrm{O}-\mathrm{H}$ groups was near $1,434 \mathrm{~cm}^{-1}$, while it disappeared in FT-IR spectrum (b). This change implied that part intermolecular hydrogen bonds were broken in the process of dissolution [26]. Therefore, cornstalk was pretreated by [EMIM]OAc in the process of dissolution.

\subsection{SEM Analyses}

SEM analyses were also employed to investigate the changes in the structure of cornstalk treated with [EMIM]OAc. SEM graphs suggested that in the original cornstalk the major component present was ordered and condensed fibrils (Fig. 2a). After treated with [EMIM]OAc (Fig. 2b), the surface of cornstalk became rough and swollen. These changes illustrated the disruption of

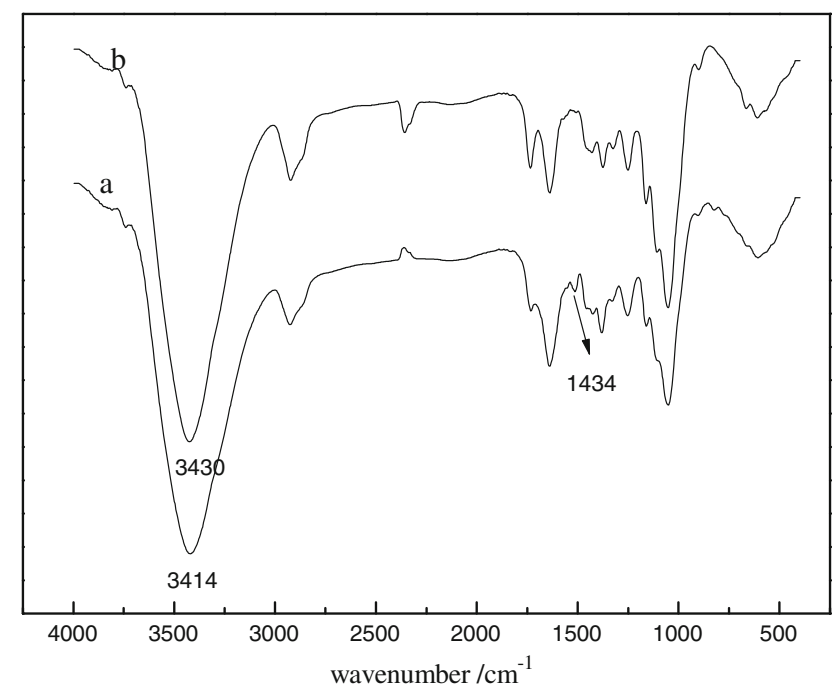

Fig. 1 FT-IR spectra of natural cornstalk (a), cornstalk treated with [EMIM]OAc $(b)$

linkages in cornstalk to a certain extent. The loosened structure provided more contact site than original cornstalk for cellulase and increased greatly the rate of enzymatic degradation [27].

\subsection{Effect of Buffer Solution on Enzymatic Degradation}

The cornstalk/ionic liquid solution were viscous and went against enzymatic degradation reaction, so a certain volume of buffer solution was added to decrease the viscosity of solution and provide the needed water in the degradation of cornstalk. The effect of kinds and $\mathrm{pH}$ of buffer solution on enzymatic degradation were firstly investigated in [EMIM]OAc system, when cornstalk concentration (the mass of cornstalk/the volume of buffer solution) $50 \mathrm{mg} /$ $\mathrm{mL}$, the ratio of enzyme and cornstalk $0.5 \mathrm{~mL} / \mathrm{g}$, reaction temperature $55^{\circ} \mathrm{C}$ and reaction time $12 \mathrm{~h}$. The results showed that the rate of enzymatic degradation in citrate buffer solution was higher than in acetate buffer solution at the same $\mathrm{pH}$ condition. This is because the longer molecule chain and lower volatility of citrate than acetate lead to the better stability. As solvent, the citrate buffer solution is more beneficial than acetate buffer solution to enzymatic degradation and in conformity with the requirement for environment. So citrate buffer solution as solvent was adopted in the following experiments. In addition, it is also can be seen from Fig. 3 that the $\mathrm{pH}$ of buffer solution also had great influence on enzymatic degradation. The rate of enzymatic degradation reached maximum at $\mathrm{pH}$ 5.0. Observation is consistent with the suitable $\mathrm{pH}$ range of that cellulase (4.2-6.0). This showed that [EMIM]OAc had no effect on the structure and surface charge distribution of 

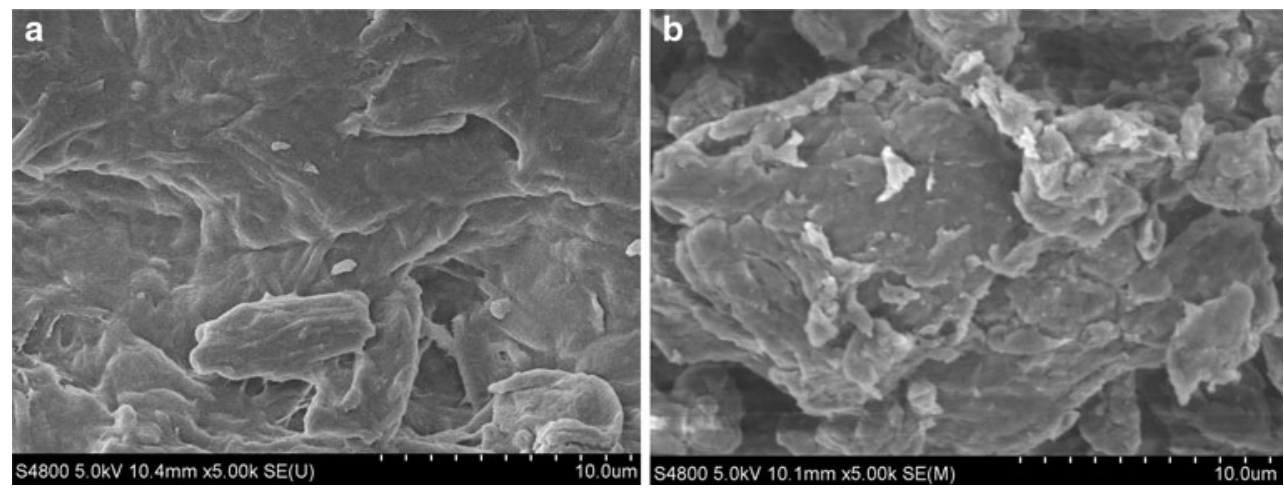

Fig. 2 SEM images of original cornstalk (a) and cornstalk treated with $[$ EMIM]OAc $(\mathbf{b})(\times 5 \mathrm{k})$

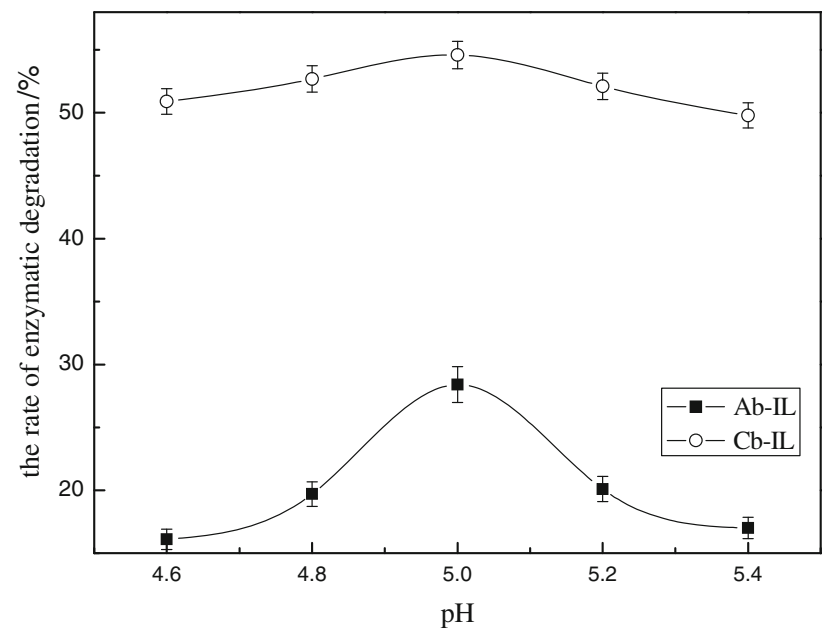

Fig. 3 Effect of buffer solution on enzymatic degradation. $A b$ Acetate buffer solution, $\mathrm{Cb}$ citrate buffer solution

cellulase, and was consistent with the effect of buffer solution on enzymatic degradation of microcrystalline cellulose [21]. Therefore, the citrate buffer solution at $\mathrm{pH}$ 5.0 was selected for further research, as described below.

\subsection{Effect of the Ratio of Enzyme and Cornstalk on Enzymatic Degradation}

The effect of the ratio of enzyme and cornstalk on enzymatic degradation were investigated in [EMIM]OAc system, when cornstalk concentration $50 \mathrm{mg} / \mathrm{mL}$, reaction temperature $50{ }^{\circ} \mathrm{C}$, reaction time $12 \mathrm{~h}$ and citrate buffer solution at $\mathrm{pH}$ 5.0. It is can be seen from Fig. 4 that two different reaction systems had same trend. At first, the rate of enzymatic degradation increased rapidly with the rise of the ratio of enzyme and cornstalk. And it reached a plateau when the ratio of enzyme and cornstalk was more than $0.5 \mathrm{~mL} / \mathrm{g}$. This is due to the contact chance among enzyme and cornstalk increased with the rise of enzyme amount. While the effective contact sites are limited, the rate of

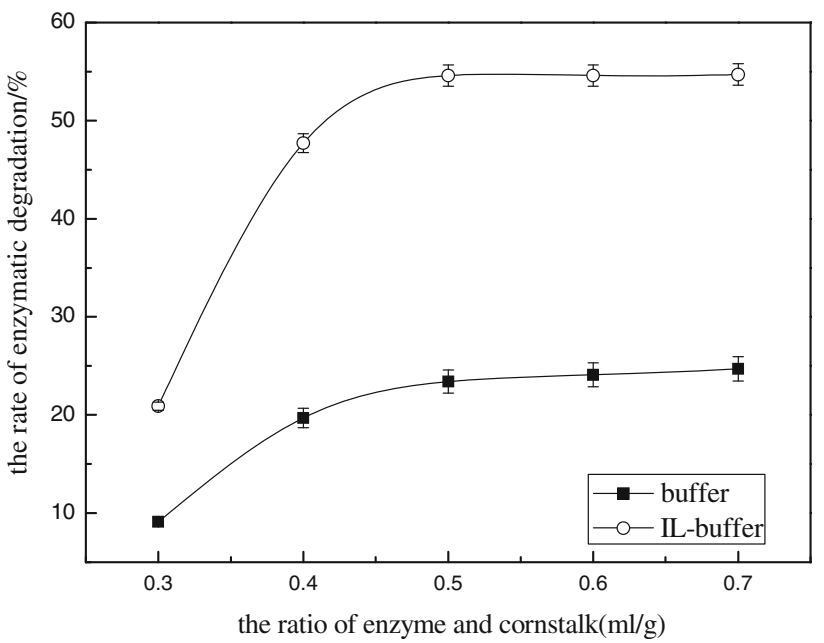

Fig. 4 Effect of the ratio enzyme and cornstalk on enzymatic degradation

enzymatic degradation did not increase when the effective contact reached the saturation state [28]. Thus, the best ratio of enzyme and cornstalk was $0.5 \mathrm{~mL} / \mathrm{g}$ in the view of enzyme economy. It also can be seen from Fig. 4 that the rate of enzymatic degradation in [EMIM]OAc system was 2.1 times higher than in conventional reaction system. The results showed that [EMIM]OAc promoted indeed the enzymatic degradation of cornstalk, and the results were consistent with FT-IR spectroscopy and SEM.

\subsection{Effect of Cornstalk Concentration on Enzymatic Degradation}

The effect of cornstalk concentration on enzymatic degradation were investigated in [EMIM]OAc system, when the ratio of enzyme and cornstalk $0.5 \mathrm{~mL} / \mathrm{g}$, reaction temperature $50{ }^{\circ} \mathrm{C}$, reaction time $12 \mathrm{~h}$ and citrate buffer solution at $\mathrm{pH}$ 5.0. It can be seen that cornstalk concentration had great influence on the rate of enzymatic degradation. The rate of enzymatic degradation increased with 


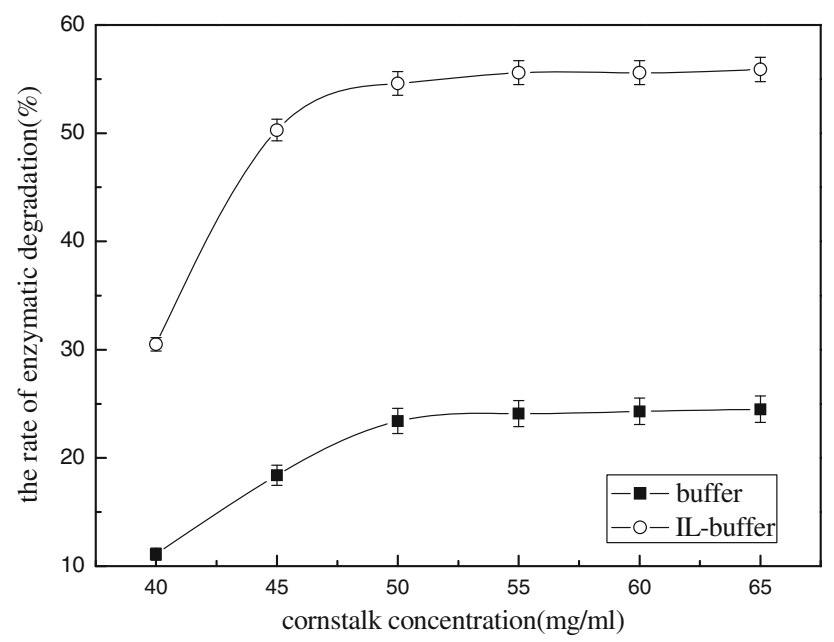

Fig. 5 Effect of cornstalk concentration on enzymatic degradation

the rise of cornstalk concentration and reached maximum at cornstalk concentration $55 \mathrm{mg} / \mathrm{mL}$. This is because the contact chance among enzyme and cornstalk increased with the rise of cornstalk concentration. The viscous reaction system hindered the enzymatic degradation reaction when the cornstalk concentration was more than $55 \mathrm{mg} / \mathrm{mL}$. Therefore, cornstalk concentration $55 \mathrm{mg} / \mathrm{mL}$ was beneficial to enzymatic degradation, and the required buffer solution addition was $3.64 \mathrm{~mL}$ in this case. It was also can be seen from Fig. 5 that the rate of enzymatic degradation in [EMIM]OAc system was significantly high compared with the conventional reaction system.

\subsection{Effect of Reaction Temperature on Enzymatic Degradation}

The effect of reaction temperature on enzymatic degradation were investigated in [EMIM]OAc system, when cornstalk concentration $55 \mathrm{mg} / \mathrm{mL}$, the ratio of enzyme and cornstalk $0.5 \mathrm{~mL} / \mathrm{g}$, reaction time $12 \mathrm{~h}$ and citrate buffer solution at $\mathrm{pH}$ 5.0. It can be seen from Fig. 6 that two different reaction systems had same trend with the change of temperature. The rate of enzymatic degradation increased obviously with the rise of reaction temperature and reached maximum at temperature $55^{\circ} \mathrm{C}$, then it decreased when temperature was more than the optimum temperature. This is because the chemical nature of cellulase is a kind of protein with catalytic activity, so it has optimum temperature. The activity of cellulase was low at low temperature and increased along with the rise of temperature. When reaction temperature was more than the optimum temperature, the activity of cellulase decreased gradually. If temperature was too high, cellulase may denature [29]. So the optimum reaction temperature was $55{ }^{\circ} \mathrm{C}$. It also can be seen from Fig. 6 that the two reaction

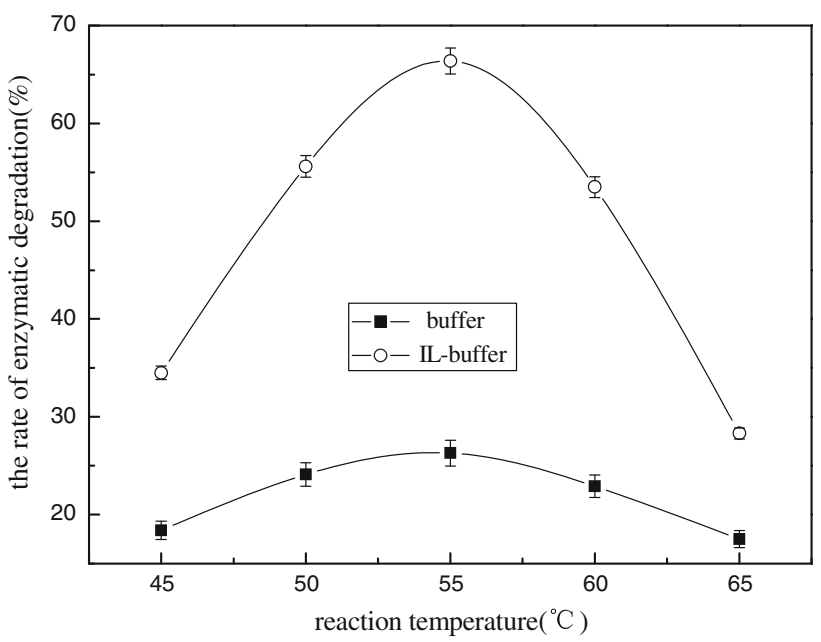

Fig. 6 Effect of reaction temperature on enzymatic degradation

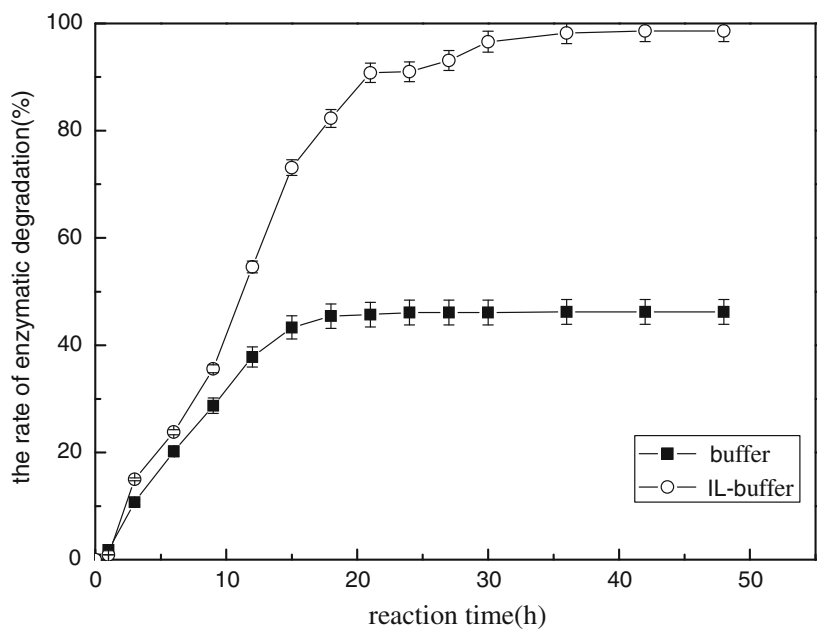

Fig. 7 Effect of reaction time on enzymatic degradation

systems had the same optimum reaction temperature and the rate of enzymatic degradation was higher in [EMI$\mathrm{M}] \mathrm{OAc}$ system. These results indicated that [EMIM]OAc not only had excellent biocompatibility, but also could promote enzymatic degradation.

\subsection{Effect of Reaction Time on Enzymatic Degradation}

The effect of reaction time on enzymatic degradation were investigated in [EMIM]OAc system (Fig. 7), when cornstalk concentration $55 \mathrm{mg} / \mathrm{mL}$, the ratio of enzyme and cornstalk ratio $0.5 \mathrm{~mL} / \mathrm{g}$, reaction temperature $55^{\circ} \mathrm{C}$ and citrate buffer solution at $\mathrm{pH}$ 5.0. The results showed that the rate of enzymatic degradation increased rapidly in the first $18 \mathrm{~h}$ and reached $80 \%$ when time was $18 \mathrm{~h}$. Then it increased slowly after $18 \mathrm{~h}$ and did not change after $30 \mathrm{~h}$. It is suggested that the reaction almost completed in $30 \mathrm{~h}$. In first $10 \mathrm{~h}$, the rate of enzymatic degradation in two 
Table 2 The reusability of [EMIM]OAc

\begin{tabular}{lll}
\hline $\begin{array}{l}\text { Times of } \\
\text { recovery }\end{array}$ & $\begin{array}{l}\text { The rate of enzymatic } \\
\text { degradation of cornstalk }(\%)\end{array}$ & $\begin{array}{l}\text { Recovery rate of } \\
\text { [EMIM]OAc (\%) }\end{array}$ \\
\hline 1 & 96.5 & - \\
2 & 91.7 & 99.8 \\
3 & 88.1 & 99.5 \\
4 & 85.3 & 99.3 \\
5 & 83.9 & 98.7 \\
\hline
\end{tabular}

different systems had little difference. The rate of enzymatic degradation of cornstalk in [EMIM]OAc system increased notably after $10 \mathrm{~h}$ and reached $96.6 \%$ after $30 \mathrm{~h}$, while it was $46.1 \%$ in conventional system. These suggested that [EMIM]OAc definitely contributed to the enzymatic degradation of cornstalk. Therefore, the optimum reaction time was $30 \mathrm{~h}$ in [EMIM]OAc system.

\subsection{The Reusability of [EMIM]OAc}

The reusability of [EMIM]OAc was investigated, when cornstalk concentration $55 \mathrm{mg} / \mathrm{mL}$, the ratio of enzyme and cornstalk $0.5 \mathrm{~mL} / \mathrm{g}$, reaction time $48 \mathrm{~h}$, reaction temperature $55^{\circ} \mathrm{C}$ and citrate buffer solution at $\mathrm{pH} 5.0$, and the results showed in Table 2 . The rate of enzymatic degradation of cornstalk was still $83.9 \%$ and the recovery rate of [EMIM]OAc was $98.7 \%$ when [EMIM]OAc was used repeatedly for the 5 th times. The results demonstrated that [EMIM]OAc had good reusability, and the recycled ionic liquid still maintain high levels of pretreatment ability. In this way, the cyclic utilization of ionic liquid reduced the cost of processing, and had great application value.

\section{Conclusions}

The enzymatic degradation of cornstalk in the IL system of [EMIM]OAc and in conventional buffer solution system were investigated. The influence of reaction conditions on the results of degradation was examined and the optimum condition for degradation was obtained. The results suggested that [EMIM]OAc showed favorable solubility and biocompatibility simultaneously. It was suggested that the molecular structure of cornstalk dissolved in [EMIM]OAc was changed, e.g. hydrogen bonds were broken (detected by FT-IR), and the crystallinity (monitored by SEM) changed significantly from crystal to an amorphous pattern. All these changes led to an increase of the contact site and the rate of enzymatic degradation. It is also found that ionic liquid [EMIM]OAc had good reusability. The cyclic utilization of ionic liquid reduced the cost of processing, and had great application value.
Acknowledgments This study was supported by the National Natural Science Foundation of China (31070520), Shandong Province Office of Education (J09LG16), Open Foundation of Chemical Engineering Subject (Qingdao University of Science and Technology), and Application foundation projects of Qingdao (12-4-1-45-nsh).

Open Access This article is distributed under the terms of the Creative Commons Attribution License which permits any use, distribution, and reproduction in any medium, provided the original author(s) and the source are credited.

\section{References}

1. Chang RHY, Jang J, Wu KCW (2011) Green Chem 13:2844

2. Gu XL, He M, Shi YJ, Li ZZ (2010) For Sci Technol 35:37

3. Tian P, Wang HJ, Ma Q (2012) Amino Acids Biot Resour 34:13

4. Ye DY, Huang H, Fu HQ, Chen HQ (2006) J Chem Ind Eng $57: 1782$

5. Schafer T, Wedel T, Nielsen VS, Skagerlind PK, Wenger K (2007) Adv Biochem Eng Biotechnol 105:59

6. Liu HC, Zhao DH, Zhang MN (2008) Jiangsu Agric Sci $1: 228-230$

7. Ren ST, Cheng KK, Song AD, Zhang JA (2011) Chin J Biotechnol 27:592-597

8. Ferreira AFC, Figueiredo AB, Evtuguin DV, Saraiva JA (2011) Green Chem 13:2764

9. Qin GD, Liu RH, Sun C (2011) J Shanghai Jiaotong Univ 45(5):11-16

10. Li HY, Jin M, Wei QQ, Li ZG (2011) Biomass Chem Eng 45:11

11. Swatloski RP, Spear SK, Holbrey JD, Rogers RD (2002) Am Chem Soc 124:4974

12. Zhang H, Wu J, Zhang J, He JS (2005) Macromolecules 38:8272

13. Dadi AP, Varanasi S, Schall CA (2006) Biotechnol Bioeng 95:904

14. Kamiya N, Matsushita Y, Hanaki M, Nakashima K, Narita M, Goto M, Takahashi H (2008) Biotechnol Lett 30:1037

15. Li CL, Knierim B, Manisseri C, Arora R, Scheller HV, Auer M, Vogel KP, Simmons BA, Sigh S (2010) Bioresour Technol 101:4900

16. Liu W, Cheng L, Zhang Y, Wang H, Yu M (2008) J Mol Liq 140:68

17. Bose S, Armstrong DW, Petrich JW (2010) J Phys Chem B 114:8221

18. Thomas VD, Mauricio MP, Sage EF (2010) Green Chem 12:1967

19. Zhao H, Baker GA, Song ZY (2008) Green Chem 10:696

20. Wang Y, Radosevich M, Hayes D, Labbe N (2011) Biotechnol Bioeng 108:1042

21. Xu CZ, Li L, Liu SW, Yu ST, Liu FS, Xie CX (2011) Polym Mater Sci Eng 27:85

22. Dzyuba SV, Bartsch RA (2001) J Heterocycl Chem 38:265

23. Tang B, Xia QY, Li CF, He XL (2006) Chin J Trop Agric 26:33

24. Liu CF, Sun RC, Zhang AP, Qin MH, Ren JL, Wang XA (2007) Food Chem 55:2399

25. Zhai W, Chen HZ, Ma RY (2007) J Beijing Univ Chem Technol $34: 138$

26. Wang B, Cao Y, Huang KL, Li HQ, Liao DK, Wang JS (2010) CIESC J 61:1592

27. Li QJ, Yin YL, Su RX, Qi W, He ZM (2009) Acta Chim Sin 67:88

28. He X, Miao YL, Chen JY, Jiang XJ, Xu ZD, Yang PK (2010) Food Sci Technol 35:47

29. Yi JQ, He YL, Su XJ, Wang KQ, Xiong XY (2011) China Brew $3: 24$ 